\title{
FORECAST OF ECONOMIC GROWTH IN ARMENIA
}

\author{
ANAHIT MKRTCHYAN \\ Armenian State University of Economics, \\ $\mathrm{PhD}$ in Economics, Assistant \\ GEVORG PETROSYAN \\ Russian-Armenian University (RAU), \\ $\mathrm{PhD}$ student \\ https://doi.org/10.52853/25792903-2021.2-amgp
}

\section{Abstract}

The article presents the development of methods for forecasting economic growth. Since the 1950s, researchers have paid more attention to economic growth research. Many analysts and economists have focused on methods of forecasting economic growth and have tried to find the principal methods that influenced it

In the 2000s, economists found out that more than 500 exogenous or indigenous factors affect economic growth. Every national economy has its specifications which makes the forecast of its economic growth uncorrelated with the others. Some of them are heavily affected by oil and gas production, the others - by financial or customer service and a dozen of influenced national economies are affected by the production in agriculture [3]. The economy of Armenia is not an exception. The author showed dynamics of Armenian economic growth, by which factors it has been affected, brought some comparisons with the region's countries. The authors used various econometric models to predict economic growth. The tiniest model, which the author constructed based on the ordinary least squares method, showed that Armenia's economic growth is mainly affected by four factors: Foreign Direct Investments, exports, national savings, and the amount of provided loans in Armenia. The quality of the mode was $98 \%$ which is very high. The most considerable affection have foreign direct investments (FDI). If the FDI increases by 1 billion dollars, gross domestic product (GDP) will rise by 4.52 billion dollars, 36\% of Armenia's GDP in 2019. The affection of Exports is not low either. If the amount of Exports increases by 1 billion dollars, that would raise gross domestic product (GDP) by 1.58 billion dollars which is $13.6 \%$ of Armenia's GDP in 2019. The author also tried to predict the economic growth of Armenia for ten years, from 2020-2029. The author used both ARIMA and SARIMA models to forecast economic growth. The results were interesting because they showed the economic crisis of 2020 due to the COVID-19 pandemic and the need for change in fiscal and monetary policies. It can be a warning sign to the ministry of Finances, Central Bank of Armenia, to consider critical changes in these policies.

Keywords and phrases: exogenous and indigenous factors, economic growth, financial crisis, ARIMA, OLS. 


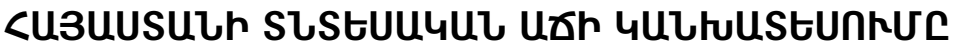

\author{
UUUKhS UपกS23Uน

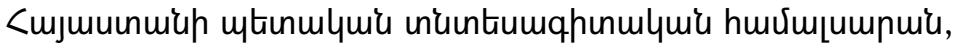

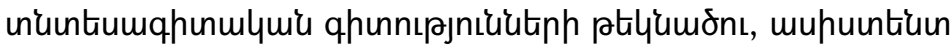

\author{
qtunกq TEsกnuзu乙

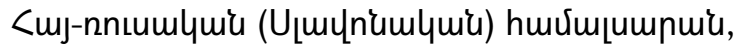

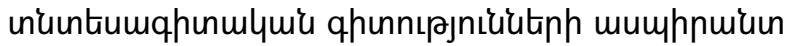

\section{<uuvunnunuqhn}

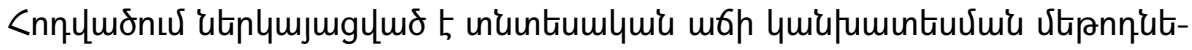

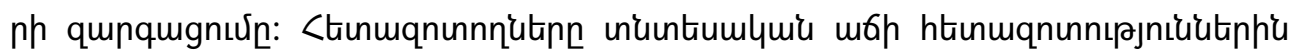

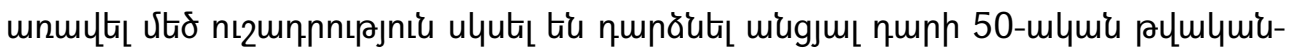

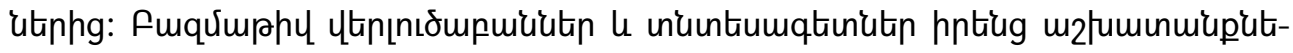

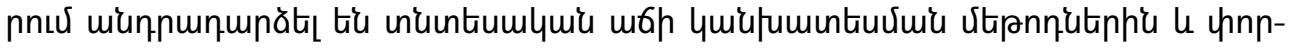

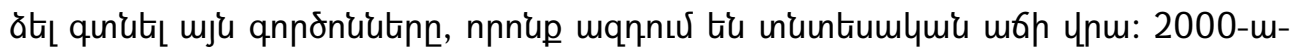

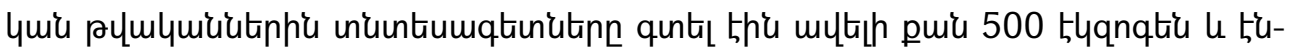

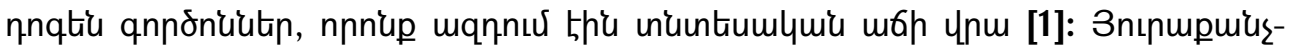

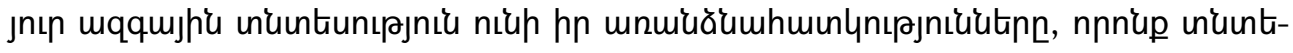

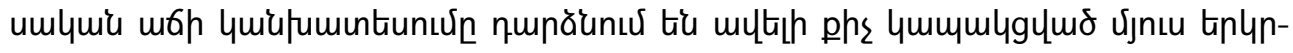

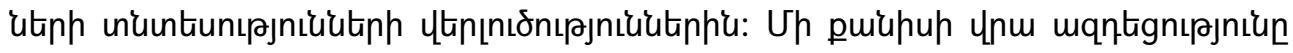

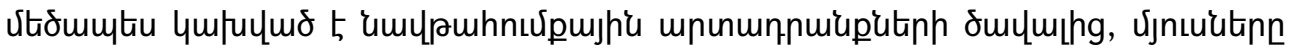

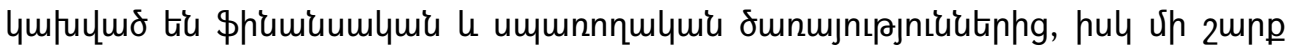

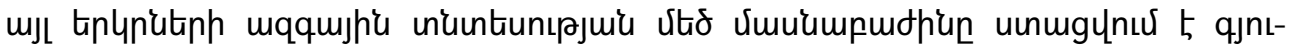

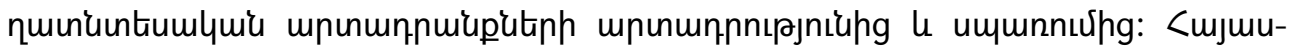

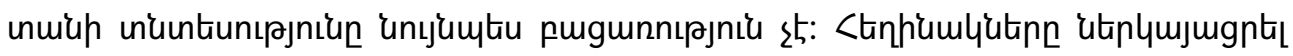

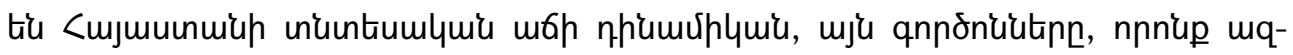

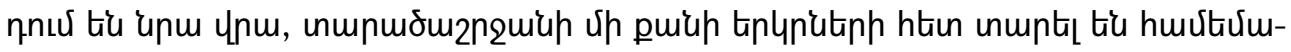

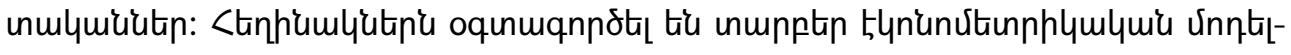

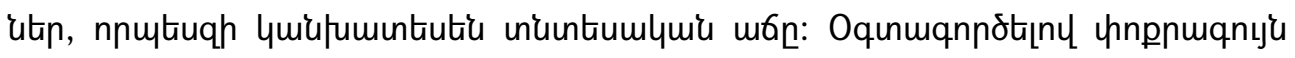

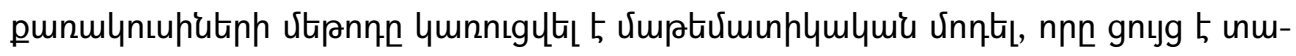

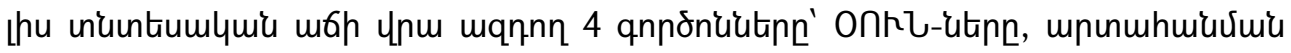

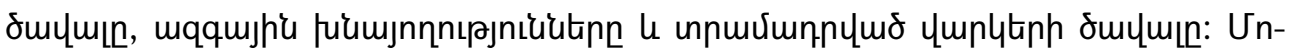

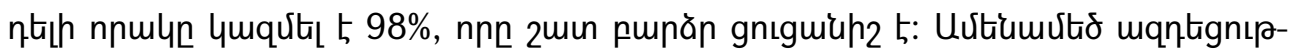




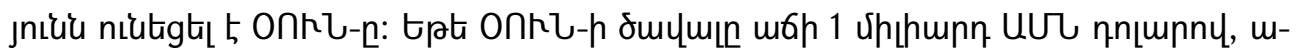

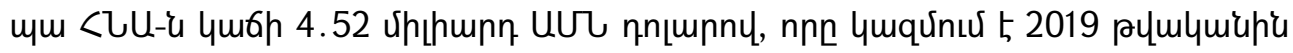

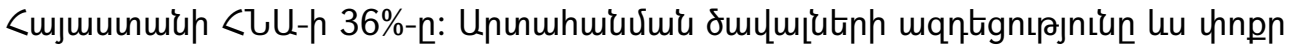

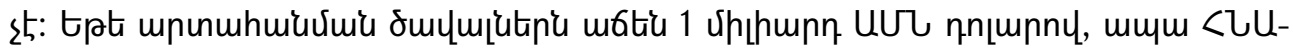

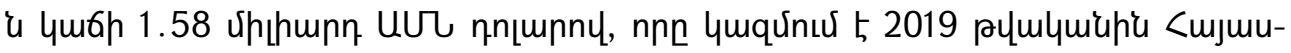

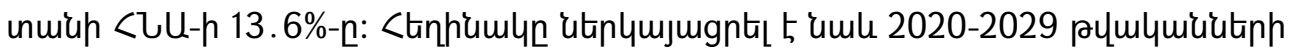

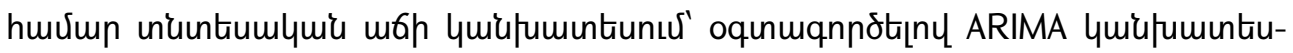

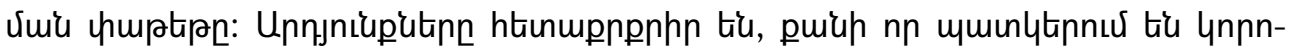

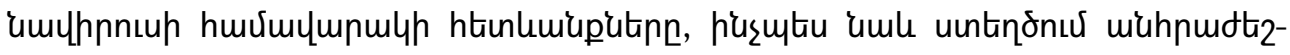

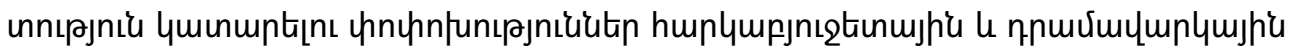

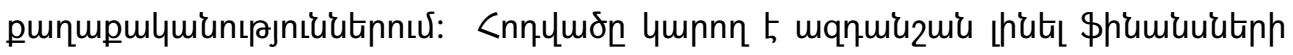

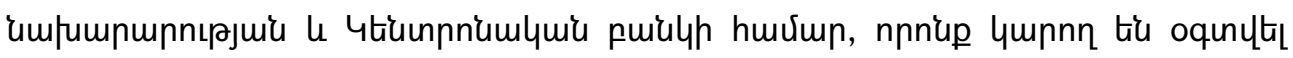

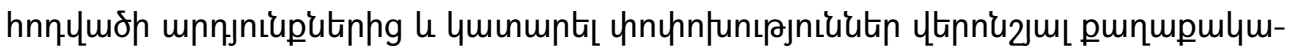

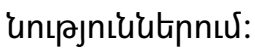

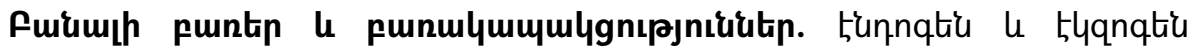

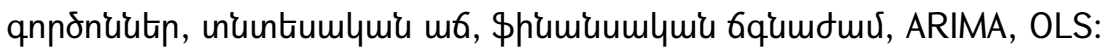

\title{
ПРОГНОЗ ЭКОНОМИЧЕСКОГО РОСТА АРМЕНИИ
}

\author{
АНАИТ МКРТЧЯН \\ Армянский государственный экономический университет, \\ кандидат экономических наук, ассистент
}

ГЕВОРГ ПЕТРОСЯН

Российско-армянский университет, кандидат экономических наук

\begin{abstract}
Аннотация
В статье представлена разработка методов прогнозирования экономического роста. С 1950-х годов исследователи уделяют больше внимания исследованиям экономического роста. Многие аналитики и экономисты уделяли внимание методам прогноза экономического роста и пытались найти те главные методы, которые влияли на него. В 2000-х годах экономисты нашли более 500 экзогенных и индогенных факторов, влияющих на экономический рост. Каждая экономика имеет свои спецификации, которые делают прогнозирование экономического роста этой страны некоррелированным с прогнозами экономических рост других стран.
\end{abstract}


Экономический рост некоторых стран зависит от продукции нефтегазовых продуктов. Экономический рост других стран зависит от финансовых и потребительских сервисов. А для некоторых сельское хозяйство является главным фактором, влияющим на экономический рост. Армения не исключение. Авторы представили динамику экономического роста Армении, факторы, которые на нее влияют, и провели сравнение с несколькими странами региона. Авторы использовали различные эконометрические модели для прогнозирования экономического роста. Используя метод наименьших квадратов, была построена математическая модель, которая показывает 4 фактора, влияющих на экономический рост, а именно: прямые иностранные инвестиции, объем экспорта, национальные сбережения и объем предоставленных кредитов. Качество модели составило 98\%, что является очень высоким показателем. ПИИ оказали наибольшее влияние. Если ПИИ вырастут на 1 миллиард долларов, ВВП вырастет на 4.52 миллиарда долларов, что составляет $36 \%$ ВВП Армении в 2019 году. Влияние экспорта тоже не маленькое. Если экспорты вырастут на 1 миллиард долларов, ВВП вырастет на 1.58 миллиарда долларов, что составляет 13.6\% ВВП Армении в 2019 году. Авторы также представили прогноз экономического роста на 2020-2029 годы с использованием пакета прогнозов ARIMA. Результаты интересны, потому что они иллюстрируют последствия эпидемии коронавируса, а также необходимость внесения изменений в фискальную и денежно-кредитную политику. Статья может быть сигналом для Министерства финансов и Центрального банка, который может использовать результаты статьи для внесения изменений в вышеуказанную политику.

Ключевые слова и словосочетания: эндогенно-экзогенные факторы, экономический рост, финансовый кризис, ARIMA, OLS.

Gross Domestic Product or (GDP) is the most common indicator to show dynamics of countries' economic growth. While trying to make some predictions, researchers use the time series of this indicator. There are tons of factors that affect economic growth, and every day there are new factors that appear to affect it. Some economists say that more than 80 significant and minor factors can somehow affect economic growth [9]. This statement predicts economic growth as a significant challenge. Some international research centres such as the World Bank, International Monetary Fund, and many others in al most every country that annually develop new methods to predict economic growth.

Researchers can either do theoretical and empirical research to find new patterns in economic growth. The goal of theoretical research is to find exogenous and endogenous factors which affect economic growth. Furthermore, that will help show the level of affection on economic growth and develop new fiscal and monetary policies if necessary [7]. 
The goal of empiric research is by using the collected data to construct mathematical models which will predict the future indexes of economic growth. In this article, the author did empirical research predicting the future values of economic growth using the time series prediction model ARIMA and did theoretical research which hel ped find the factors that affected economic growth and cal cul ated the level of affection via the OLS method.

A common opinion states that research uses more endogenous or exogenous factors in their study as they find their roots from microeconomics and agglomerate another factor, making the model more useful [4]. But some researchers say that using only endogenous factors in a model can become useless in a state of crisis, and there will be a need to construct a new model which consists of other endogenous factors [5]. That is why the optimal solution for the model construction is using both endogenous and exogenous factors, which the author did in this article.

This article aims to show the dynamics of Armenia's economic growth through its existence as an independent country and then to forecast the future values of economic growth.

This diagram shows the GDP of Armenia from 1990-2019 [2].

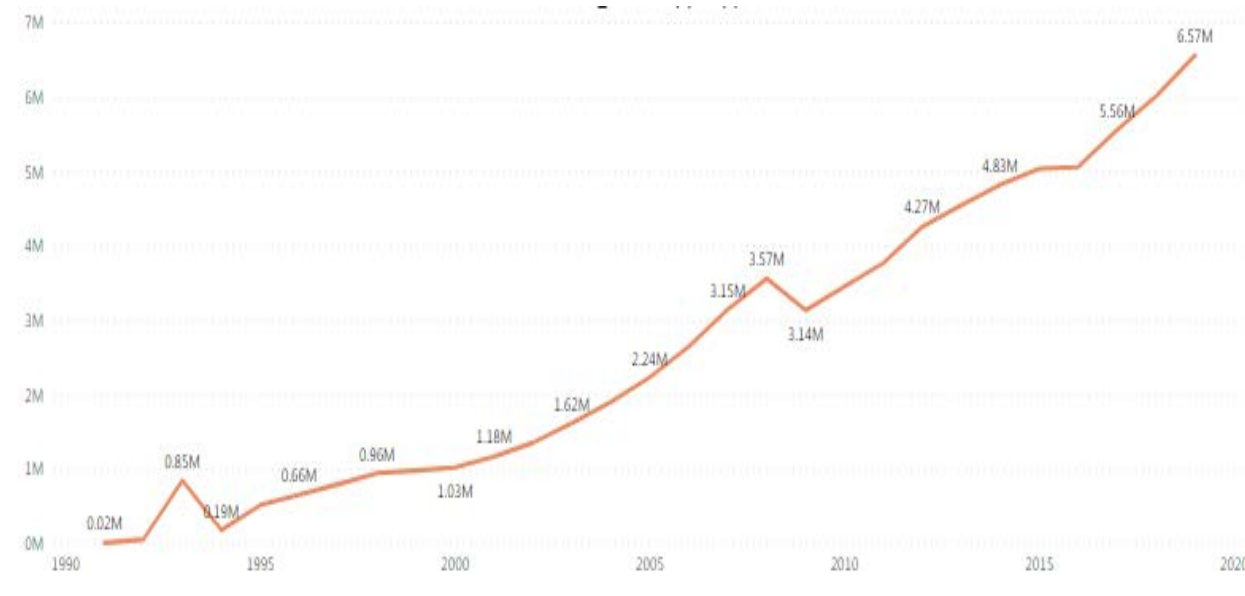

After the disintegration of the Soviet Union, Armenia's economy appeared in a bad situation. Not only did the main source of money flow disappear, but the earthquake of Spitak happened in 1988, which took the lives of more than 25000 people and the war with neighbour Azerbaijan started and lasted till 1994. The battle was victorious, but it took a lot of resources from the country. Then, after the collapse of socialism, the era of capitalism started in Armenia. That was followed by the privatization of big companies, which were the heart of the economy, and they began to work with less productivity, which brought the country near collapse. But afterwards, the country's economy started to recover, and from 2002 till the financial crisis in 2008, 
Armenia's GDP grew by $162 \%$. But in 2009 , due to the financial crisis, the economic loss was tremendous $-14.1 \%$.

This diagram shows the dynamics of the economic growth of Armenia from 1990-2019 [10].

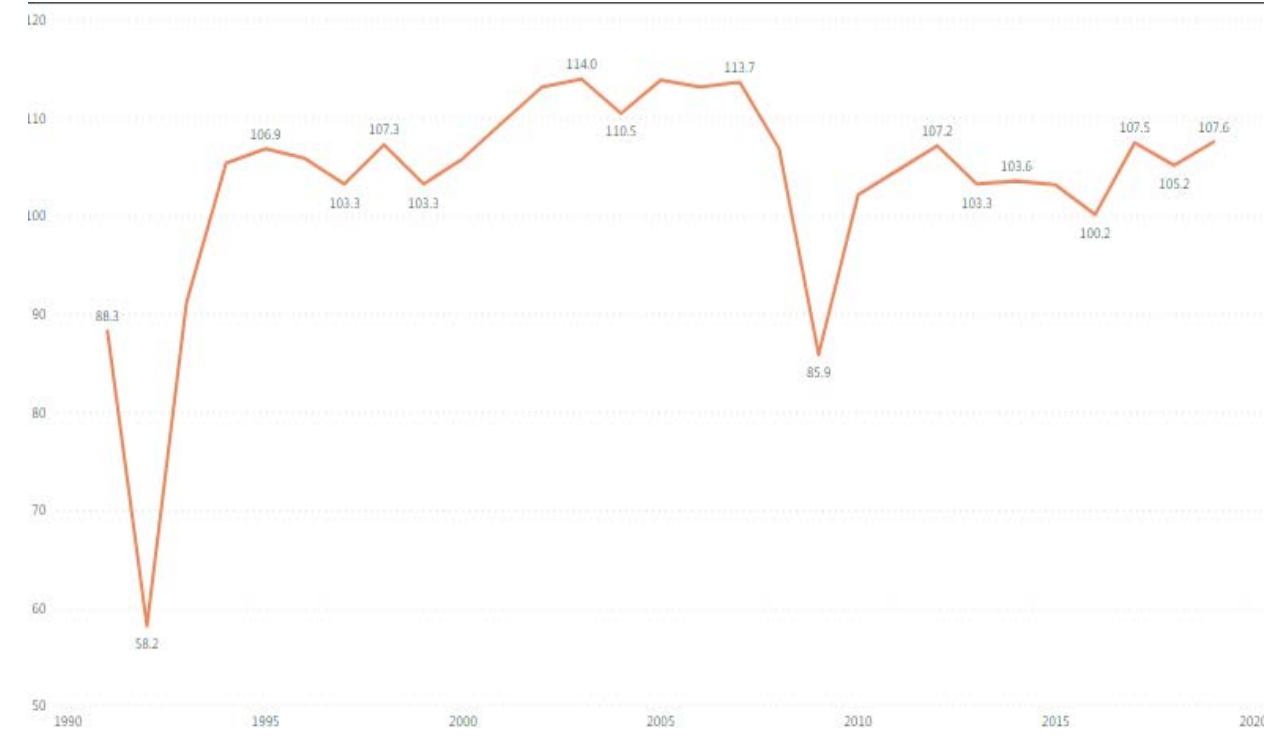

In 2016 the third financial crisis happened in Armenia. Affected by the sanction on the Russian Federation and the depreciation of the Ruble, which caused the transfers from Russia to Armenia, economic growth slowed down a lot. Still, it then recovered in the next year due to the right chosen fiscal and monetary policies.

Researches still predict the future values of the economic growth of Armenia, which is affected by COVID-19 and the second war with Azerbaijan. Some researchers predict that economic loss in 2021 will be $-4.5 \%$ in Armenia. That is not the worst indicator in a region. Georgia, Turkey and Iran are predicted to have -5.5\% economic loss.

After analyzing the dynamics of economic growth, there is a need for predictions. The first method used by the author to predict the future values of economic growth in Armenia is ARIMA timeseries econometric model. The first step is to analyze the collected data to understand its usability. In this diagram are shown the results of the ARIMA model for the data from 1990-2019. The author used Python programming language to do the cal culations [6]. 
ARMA Model Results

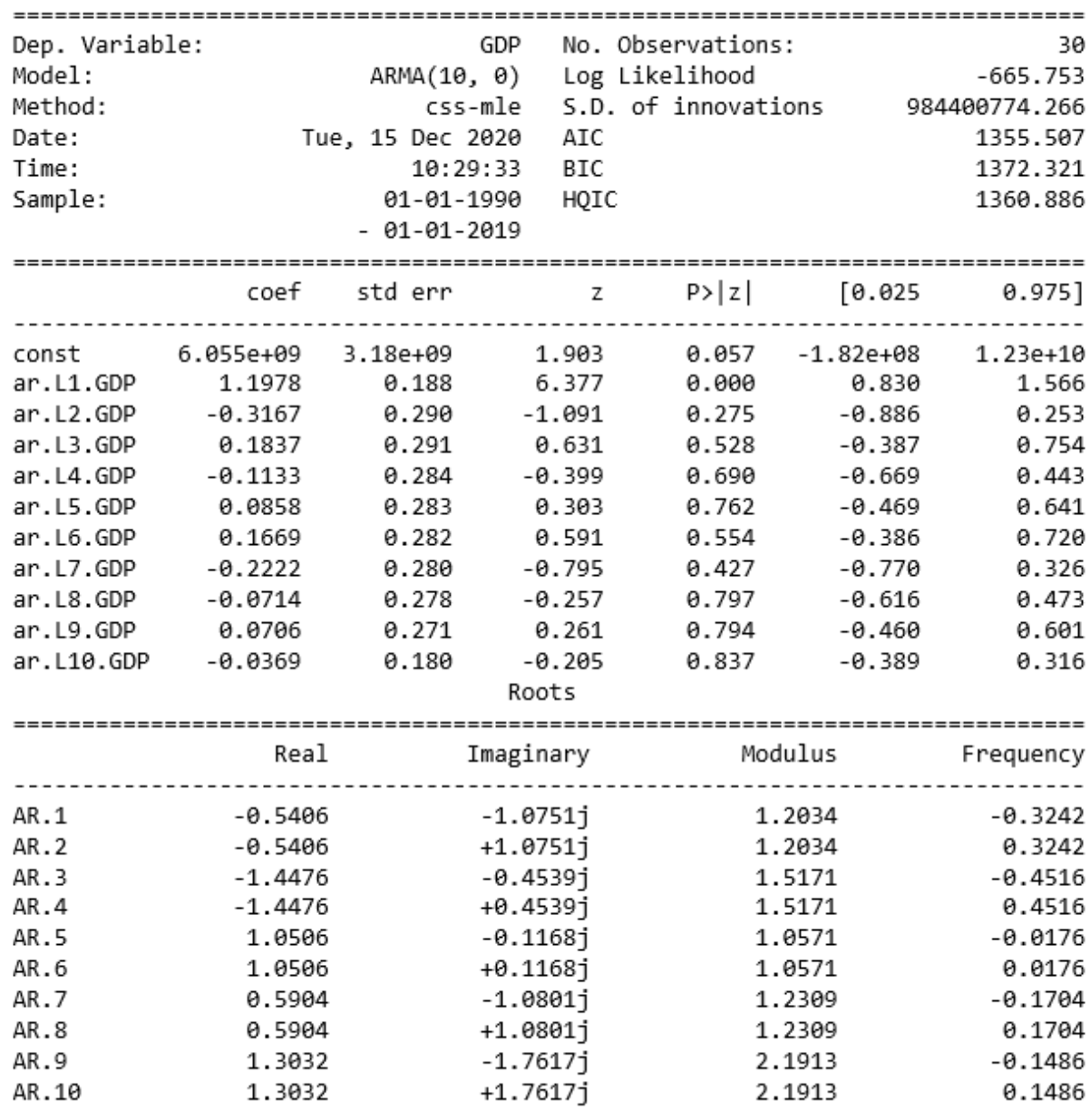

From this diagram this statement it can be processed that the constant annual value of GDP equals 6.1 billion USD, and the factors that affect economic growth add the remaining value to generate the overall yearly GDP. In 2019 Armenia's GDP was 13.63 billion USD.

To check the accuracy of this model, the author constructed the autocorrelation graph, which shows the lags or years which can be used for prediction.

This diagram shows the autocorrelation graph indicating the limits of lags collected to predict the future values of economic growth. 


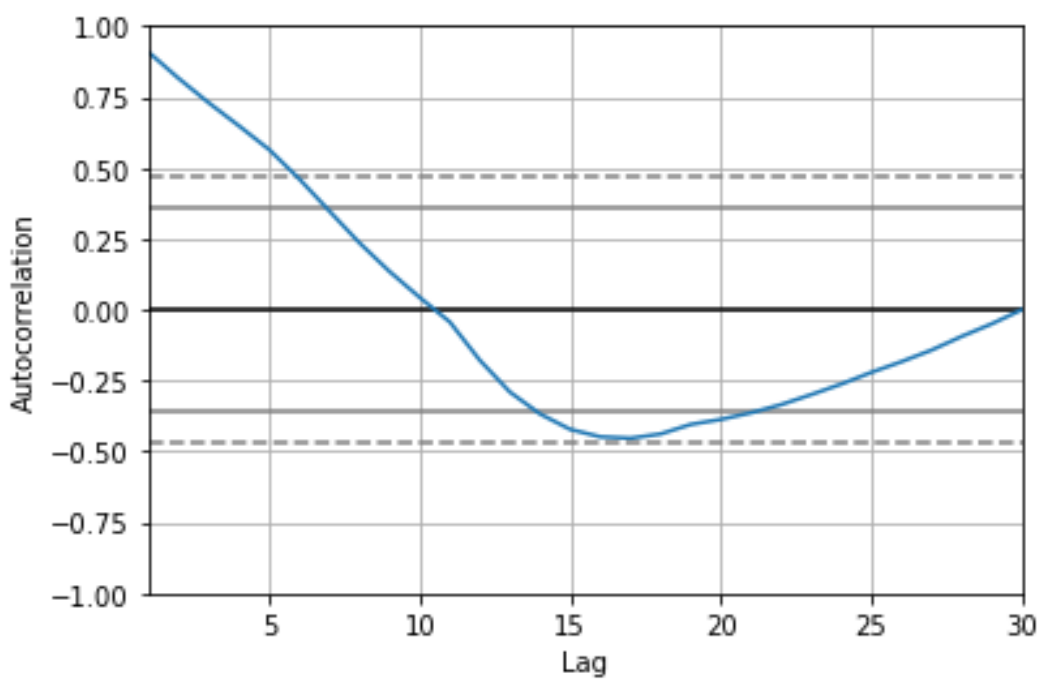

From this graph can be processed the statement that only the first five years are not eligible to use in prediction or do not affect predictions much as the following years. It is logical because in the first five years, as told previously, war and earthquakes happened, which happens not so often and are unpredictable.

Using statsmodels library's SARIMAX prediction model in this graph is shown the prediction of economic growth from 2020-2029.

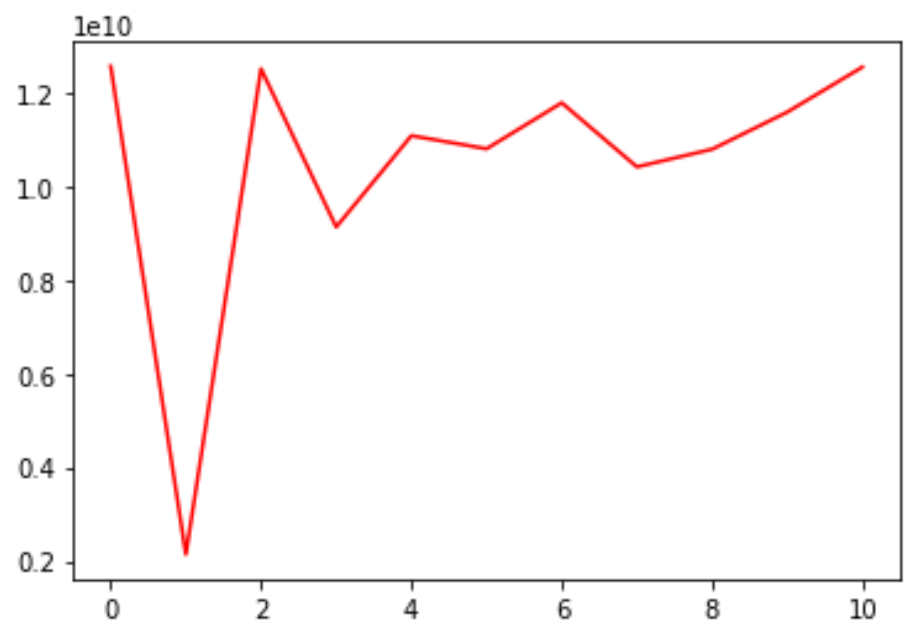

Shown results make interest because they predicted the economic loss in 2020 and the recovery in 2021. GDP mean from 2021-2027 is 12.5 billion USD which is less than in 2019. And only in 2028 model indicates economic growth. These results show a crucial need to change both fiscal and monetary policies, which can bring economic growth earlier than 2028. 
After the prediction, there was a need to understand the main factors which affect economic growth [8]. At first, eight factors were chosen to construct econometric on. Still, the correlation matrix of affecting factors made the author choose only 4 of them, which are foreign direct investments (FDI), Exports (exp), National Savings (Sav) and Provided Loans (Loan).

The regression function had this appearance:

GDP $=\alpha+\beta_{1}$ FDI $+\beta_{2}$ exp $+\beta_{3}$ Loan $+\beta_{4}$ Sav $+\varepsilon_{i}$

Using OLS method of statsmodels library author calculated the results of affection of chosen factors.

OLS Regression Results

\begin{tabular}{|c|c|c|c|}
\hline Dep. Variable: & GDP & R-squared: & 0.981 \\
\hline Model: & OLS & Adj. R-squared: & 0.978 \\
\hline Method: & Least Squares & F-statistic: & 287.3 \\
\hline Date: & e, 15 Dec 2020 & Prob (F-statistic): & $1.21 \mathrm{e}-18$ \\
\hline Time: & $13: 22: 55$ & Log-Likelihood: & -584.16 \\
\hline No. Observations: & 27 & AIC: & 1178 . \\
\hline Df Residuals: & 22 & BIC: & 1185. \\
\hline Df Model: & 4 & & \\
\hline Covariance Type: & nonrobust & & \\
\hline \multicolumn{4}{|c|}{ 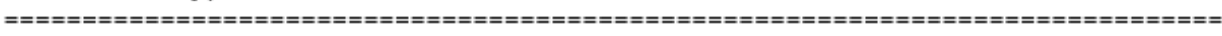 } \\
\hline coef & std err & {$[0.025$} & $0.975]$ \\
\hline $2.379 e+08$ & $2.55 \mathrm{e}+08$ & $-2.91 e+08$ & 7. $67 e+08$ \\
\hline 4.5224 & 0.952 & 2.547 & 6.497 \\
\hline 1.5759 & 0.295 & 0.963 & 2.188 \\
\hline 0.6288 & 0.303 & 0.001 & 1.257 \\
\hline Loan $\quad 1.4799$ & 0.793 & $1.865 \quad 0.076$ & 3.126 \\
\hline \multicolumn{4}{|c|}{ 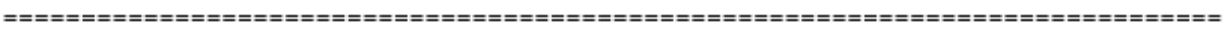 } \\
\hline Omnibus: & 2.497 & Durbin-Watson: & 0.599 \\
\hline Prob(Omnibus): & 0.287 & Jarque-Bera (JB): & 1.240 \\
\hline Skew: & -0.063 & $\operatorname{Prob}(J B):$ & 0.538 \\
\hline Kurtosis: & 1.958 & Cond. No. & $5.82 \mathrm{e}+09$ \\
\hline
\end{tabular}

Regression function gained this appearance:

GDP $=2.4$ billion $+4.52 \mathrm{FDI}+1.58$ expe+0.63 Sav +1.48 Loan

The model accuracy or Adj, R-squared is $98 \%$ which is good. The factors are significant in a 93-95\% ratio. The F-statistic which shows whether factors and economic growth are linear correlated is near to 0 .

The results show that if foreign direct investments grow by 1 billion USD then GDP will grow by 4.52 billion USD and so on. 


\section{REFERENCES}

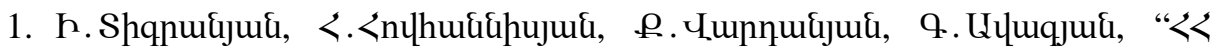

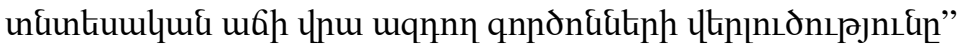

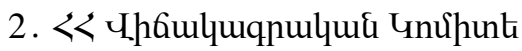

3. Cobb C. W. and Douglas P. H., A theory of production. American Economic Review 18(1), 1928, tr 139-165: Supplement, Papers and Proceedings of the Fortieth Annual Meeting of the American Economic Association

4. Jones, C.I., (1995a) Time series tests of endogenous growth models, Quarterly J ournal of Economics, 110: 495-525

5. Kocherakota, N. R. and Mu Yi, K., (1996) A simple time series test of endogenous vs exogenous growth models: An application to the United States, Review of Economics and Statistics, 78: 126-134

6. Greiner, A., Semler, W. and Gong, G., (2004) The Forces of Economic Growth: A TimeSeries Perspective, (Princeton, NJ: Princeton University Press)

7. Mankiw, N. G., Romer, D. and Weil, D. N., (1992) A contribution to the empirics of economic growth, Quarterly J ournal of Economics, 107: 407-38

8. Rao, B. B. (2007a) Estimating short and long run relationships: A guide to the applied economist", forthcoming, A pplied Economics

9. Hoover, K. and Perez, S. (2005) Truth and robustness in cross-country growth regressions, Oxford Bulletin of Economics and Statistics, 76: 763-798

10. https://data. worldbank.org/indicator/NE.GDI.TOTL.CN?locations=AM

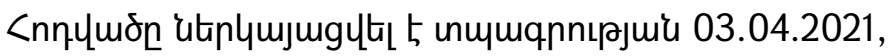
nunnıluytts 5 unmmqnnıрjuiu 10.05.2021 